\title{
MEASURING THE INFLUENCE OF TAX ADVERTISING AND SERVICES AS EXTERNAL FACTORS ON TAXPAYER COMPLIANCE
}

\author{
Eko Retno Indriyarti ${ }^{1)}$, Michael Christian ${ }^{2)}$ \\ ${ }^{1)}$ Fakultas Ekonomi Bisnis, Universitas Trisakti \\ 2) Program Studi Manajemen, Universitas Bunda Mulia \\ Email :ekoretno@trisakti.ac.id
}

Diterima 11 Januari 2021 / Disetujui 14 Juli 2021

\begin{abstract}
Amid the continuing increase in the number of taxpayers in Indonesia, it is expected that the amount of tax revenue for the state will continue to increase. The increase in the amount of revenue is aimed at optimizing tax functions, namely budgetary, distribution and stability functions. However, the success of this tax revenue is strongly influenced, one of which is the taxpayer compliance to fulfill its obligations. Apart from internal factors that come from individual taxpayers, external factors have an important role in shaping taxpayer compliance. Several studies still show different results on these external factors on their influence on Taxpayer Compliance. This study aims to explain and analyze the influence of tax and tax service advertisement socialization factors on taxpayer compliance in Jakarta. This research is a quantitative study using multiple regression analysis. The analytical tool used in this study is the Social Package for the Social Sciences (SPSS 25.0). The results of this study explain that taxpayer compliance is influenced by tax advertising socialization. In addition, the Taxpayer Compliance variable is also influenced by tax services. Simultaneously, tax dissemination and services also affect taxpayer compliance. With limitations on the specifications of the external factors used, this study also emphasizes the characteristics of taxpayers such as novice taxpayers, which is an interesting input to be carried out in subsequent studies. The level of tax knowledge for the group taxpayers will be closely related to the awareness of taxpayers in carrying out their obligations. This has an indirect impact on the level of compliance as a taxpayer.
\end{abstract}

Keywords: Taxpayer compliance, advertising, services

\begin{abstract}
ABSTRAK: Di tengah terus meningkatnya jumlah wajib pajak di Indonesia diharapkan dapat terus meningkatkan jumlah penerimaan pajak bagi negara. Peningkatan jumlah penerimaan ini bertujuan untuk mengoptimalkan fungsi-fungsi pajak yaitu fungsi budgeter, distribusi, dan stabilitas. Namun demikian keberhasilan penerimaan pajak ini sangat dipengaruhi salah satunya dari Kepatuhan Wajib Pajak untuk memenuhi kewajibannya. Selain faktor internal yang berasal dari individu wajib pajak, faktor eksternal memiliki peran penting dalam membentuk kepatuhan wajib pajak. Beberapa penelitian masih menunjukkan hasil yang berbeda pada faktor-faktor eksternal tersebut terhadap pengaruhnya pada Kepatuhan Wajib Pajak. Penelitian ini bertujuan untuk menjelaskan dan menganalisis pengaruh faktor sosialisasi iklan pajak dan layanan pajak terhadap Kepatuhan Wajib Pajak di Jakarta. Penelitian ini merupakan penelitian kuantitatif dengan menggunakan analisis regresi berganda. Alat analisis yang digunakan pada penelitian ini yaitu Social Package for the Social Sciences (SPSS 25). Hasil penelitian ini menjelaskan bahwa Kepatuhan Wajib Pajak dipengaruhi oleh Sosialisasi iklan pajak. Selain itu, variabel Kepatuhan Wajib Pajak juga dipengaruhi oleh Layanan pajak. Secara simultan, Sosialisasi dan Layanan pajak turut mempengaruhi Kepatuhan Wajib Pajak. Dengan keterbatasan pada spesifikasi faktor eksternal yang digunakan, penelitian ini menekankan juga pada karakter-karakter wajib pajak seperti Wajib Pajak pemula menjadi salah satu masukan yang menarik untuk dilakukan pada penelitian berikutnya. Tingkat pengetahuan pajak bagi wajib pajak kelompok tersebut akan sangat berhubungan dengan kesadaran wajib pajak dalam menjalankan kewajibannya. Hal ini secara tidak langsung berdampak pada seberapa tinggi kepatuhan sebagai Wajib Pajak.
\end{abstract}

Kata Kunci: kepatuhan wajib pajak, iklan, layanan 


\section{Introduction}

Taxes as it is known have general functions, namely a budgetary function (financing of national development or other state expenditures), a regulatory function (regulation of social and economic policies), a distribution function (social welfare) and a stability function (stabilization of economic conditions) (Maulida, 2018). Based on data from the Directorate General of Taxation's Destination Statement for 2015-2019 (table 1), it can be explained that the amount of tax revenue in 5 years has increased. This is in line with the increasing number of taxpayers during that period. In 2015, the amount of tax revenue was 1,294 trillion rupiah which then increased to 2,329 trillion rupiah in 2019 . There was an approximately 2-fold increase in the amount of tax revenue. Apart from the increase in the number of taxpayers, the increase also occurred in the SPT aspect through e-filing. A significant increase occurred in 5 years, where in 2015 the number of SPTs through e-filing was 2 million then in 2019 it increased to 24 million. This explains that along with the increase in taxpayers, it can also be explained that from year to year the understanding of taxpayers regarding taxation includes taxation service facilities that can be used. This understanding of taxpayers can support forming taxpayer compliance to fulfill their obligations.

Table 1. Destination Statement of the Directorate General of Taxes (2015-2019)

\begin{tabular}{lrrrrr}
\hline \multicolumn{1}{c}{ Indicator } & $\mathbf{2 0 1 5}$ & $\mathbf{2 0 1 6}$ & $\mathbf{2 0 1 7}$ & $\mathbf{2 0 1 8}$ & \multicolumn{1}{c}{$\mathbf{2 0 1 9}$} \\
\hline Tax ratio & $13.2 \%$ & $14.2 \%$ & $14.6 \%$ & $15.2 \%$ & $16 \%$ \\
Tax revenue & $1.295 \mathrm{~T}$ & $1.512 \mathrm{~T}$ & $1.737 \mathrm{~T}$ & $2.007 \mathrm{~T}$ & $2.329 \mathrm{~T}$ \\
SPT via e-filing & $2 \mathrm{M}$ & $7 \mathrm{M}$ & $14 \mathrm{M}$ & $18 \mathrm{M}$ & $24 \mathrm{M}$ \\
Number of registered taxpayers & $32 \mathrm{M}$ & $36 \mathrm{M}$ & $40 \mathrm{M}$ & $42 \mathrm{M}$ & $44 \mathrm{M}$ \\
\hline${ }^{*} T=$ trillion rupiah; $M=$ million rupiah & & & & &
\end{tabular}

Source: Directorate General of Taxes (2019)

In addition, several factors that can affect taxpayer compliance in the KPP Kembangan area, Jakarta such as tax authorities, tax sanctions, tax dissemination and perceptions of tax effectiveness (Arviana \& W, 2018). In different areas such as Surabaya, taxpayer compliance is influenced by factors such as taxpayer awareness, the attitude of tax authorities, applicable tax laws, and the rational attitude of the pros and cons of fulfilling obligations as taxpayers (Siat \& Toly, 2013). Meanwhile at KPP Pratama Jambi, taxpayer compliance is influenced by factors such as taxpayer awareness, knowledge and understanding of taxpayers about taxation, perceptions of the effectiveness of the tax system and tax sanctions (Afritenti, Fitriyani, \& Susfayetti, 2020). Studies have used various factors to explain their effects on taxpayer compliance. However, as time goes by and with the increasing diversity of taxpayers, the latest testing is still needed which continuously explains the dominant factors both internal and external that affect taxpayer compliance. This is also in line with the explanation (Marandu, Mbekomize, \& Ifezue, 2015) which states the background that although various tax compliance studies have been raised, there is still a lack of collective adequacy of the factors used. This also explains that from year to year with the improvement or adjustment of tax regulations and the diversity of taxpayer characters (age, occupation, education, location of residence and so on), the taxpayer compliance factors still need to be continuously studied as in this study.

The identification of the problem in this study is that there are still differences in the results of the research that explain the influence of tax advertising socialization factors on tax compliance. Likewise with the tax service factor as part of an external factor for its effect on tax compliance. Not only partially, if it is tested simultaneously whether the two external factors are able to 
influence taxpayer compliance, it remains to be proven. Thus, this study is expected to provide improved results on existing research gaps.

Based on the explanation above, this study aims to explain as well as analyze the effect of advertisement socialization and tax services as external factors on taxpayer compliance in Jakarta. The theoretical implication of this research is expected to contribute to the enriching public understanding as mandatory for external factors that consciously or unconsciously affect tax compliance. In practical implications, the results of this study are expected to be a consideration for the tax service office (KPP), especially in implementing consistent service quality standards for each taxpayer.

\section{Hypothesis Development}

Tax compliance can be explained as a form of obedient action in implementing tax laws and regulations (Hadiwijaya \& Febrianty, 2019). In a concept that is not much different, tax compliance is defined as a condition for a taxpayer to fulfill all tax obligations and simultaneously use his taxation rights (Juniarti, Noersanti, \& Susanti, 2018). This definition is almost the same as the operational definition used in this study where tax compliance is described as an act of taxpayers to fulfill their obligations as well as to get their rights in the taxation field in accordance with the rules and regulations in force in Indonesia. In this study, compliance referred to is the compliance of individual taxpayers with taxpayers in Jakarta in general. The indicators used to explain Tax Compliance in this study are the timeliness of the taxpayer to provide tax reporting, the suitability of the amount of tax reported, and the willingness to pay sanctions if any. Compliance in carrying out obligations as taxpayers is related to the concept of motivation from individual behavior. Various studies have explained that an individual's understanding of taxation and its regulations will determine the motivation that is formed to perform their obligations. Damayanti (2012) in his research that uses the Theory Planned Behavior approach to changes in the tax culture in Indonesia explains that tax compliance is influenced by the intention of individuals as taxpayers. However, the intention itself is motivated by the individual's own attitude towards tax compliance. Therefore, strategies to increase positive attitudes to carry out obligations as taxpayers and instill subjective norms in the social environment regarding the importance of being obedient as taxpayers are things that need to be continuously carried out. Other studies explain that normative expectations of compliance and sanctions are determinants of taxpayer compliance in Zonguldak, Turkey (Benk, Çakmak, \& Budak, 2011). Furthermore, this research also explains that if there is a policy adjustment on taxation, efforts to link it with moral and social norms must also be considered so that the intention of taxpayers to voluntarily carry out their obligations is maintained and continues to increase. Meanwhile, Hai \& See (2011) in their research in Malaysia explained that taxpayer attitudes, especially regarding the view of tax costs and the fairness aspect of the tax system, have an influence on tax noncompliance. In addition, the subjective norms and background of taxpayers (gender and age) are also supporting factors for the form of taxpayer noncompliance intentions.

Apart from internal factors in tax compliance, external factors also provide various interesting perspectives in determining taxpayer compliance. In simple terms, external factors come from outside the obligatory individual itself (Wulan, Suhartini, \& Bahri, 2018). External factors such as information technology, tax audits and tax courts in a country can help avoid tax evasion (Tarmidi, Suryati, \& Purwaningsih, 2020). In Indonesia, several studies that discuss external tax factors use several factors such as advertisements, tax officer services, sanctions, tax amnesty, social norms and so on. Sulila (2019) in her 
research uses advertising factors to explain their effect on tax compliance. In this study, the advertising aspect is the effectiveness of tax advertisements in the form of billboards and the content of information from the advertisements submitted becomes the independent variable. In this case, the effectiveness of billboards relates to the success aspects of advertisements made in supporting the success of tax revenue. Meanwhile, from the content side of the advertisement, it relates the success aspect of the information conveyed where taxpayers must pay taxes on time and in the correct amount. The results of this study also explain that both partially and simultaneously the effectiveness of advertisements and the content of advertisement information delivered affects taxpayer compliance. However, this study also explains that it is necessary to continue extensification in the form of socialization to maximize the effectiveness of tax revenues. Research that uses advertising factors in measuring taxpayer compliance was also conducted by Trisnawati , E., \& Putri (2014) where the results of the research explained that there was an effect of advertising on taxpayer compliance. In this study, the indicators used to explain the advertising variables are the quality of the advertisements, the content of advertisements delivered and the public's perceptions. One of the limitations and recommendations of study is that it can use even more diverse demographics at different times. This means that it is necessary to carry out the similar research later date with a more diverse sample character. From the aspect of advertising content itself, Christian (2017) in his research has explained that tax advertisements, especially those that are informative, can form taxpayer awareness to fulfill their obligations. However, from a different perspective, research conducted by Wulan et al., (2018) explains that advertisements regarding taxes do not affect tax compliance. This research indicates that it is possible that the advertisements served are less effective or not carried out in a sustainable manner. This research is in line with research conducted by Waluyo (2014) which also explains that advertising does not affect taxpayer compliance in carrying out their obligations. This study uses a content and frequency approach to explain the effectiveness of a tax authority advertisement. Based on the explanation has been given, the hypothesis proposed in this study are:

H1: The socialization of tax advertisements affects on taxpayer compliance.

Information technology in the media for delivering advertisements continues to develop from time to time so that the effectiveness of advertisements can differ. Informative, educational, and creative aspects can be a determining factor for the success of advertisements regarding taxation in shaping taxpayer awareness. Coupled with the still found differences in the results of studies that use advertising factors in explaining taxpayer compliance factors, one of the objectives of the study is to analyze the effect of advertising socialization variables on taxpayer compliance. The operational definition of tax advertising socialization in this study is a form of tax information to the public which aims to invite taxpayers to carry out their tax obligations. With so many aspects of advertising socialization used in various studies, this study focuses on the main indicators in the form of advertising socialization, namely the quality of the information content of the advertisements displayed and the frequency of the display of advertisements regarding the tax.

Another external factor related to taxpayer compliance is the Tax Service itself. Tax services in this study refer to the notion of communication to provide tax information services to form a taxpayer's understanding of taxation. The indicators used in this variable are consistency of services provided by tax officials, tax provisions and tax information systems. Hary, Kertahadi, \& Riyadi, (2014) in their research at the Tax Service Office of Pratama Malang Utara and Malang Selatan succeeded in explaining that the service offices in the two regions had met excellent service quality standards. This study uses aspects of tax services such as the ability of the tax officer, the attitude of the 
tax officer, the attention given, the actions taken and the appearance of the tax officer. This study also explains that training and supervision need to be carried out on an ongoing basis to maintain excellent service. These results are in line with other studies such as Awaluddin \& Tamburaka (2017) and Savitri \& Musfialdy (2016) which also explain that the quality of tax services affects tax compliance. Meanwhile, different results are explained by Rahmawati \& Yulianto (2018) where the perception of tax service quality does not affect taxpayer compliance at KPP Pratama Semarang Candisari. This study indicates the inconvenience of service felt by taxpayers because the research period was conducted in the period approaching the reporting period for Annual Tax Return (SPT), resulting in long queues. Lack of understanding of taxpayers' knowledge in the use of e-spt and e-filing on computers and online-based services is indicated to be the cause of limited-service delivery. In relation to the understanding of taxpayers, Andreas \& Savitri (2015) from the results of their research explained that taxpayer awareness itself is a full factor that can mediate the relationship between quality services and tax compliance. This means that taxpayers who have awareness through sufficient knowledge in understanding taxation can help form excellent tax services. Other studies that explain that service quality has no effect on mandatory compliance, namely Setiyoningrum, Tinangon, \& Wokas (2014). This research indicates that this result is due to the inadequate quality of tax services provided to taxpayers at KPP Manado. Based on this explanation, there are still differences in the results of research using the service quality variable on tax compliance. This is the background of this research with the following hypothesis:

\section{H2: Tax services affect Taxpayer Compliance.}

The two external factors above (tax advertisement socialization and taxation services) have been described as having a relationship with the compliance factor for taxpayers. This is consistent with the results of research conducted by Wulan et al., (2018) were advertising factors and tax service quality affect Taxpayer Compliance. However, as previously explained, there are still partially different results from the quality of service and socialization of Taxpayer Compliance, so to prove it, it is necessary to conduct the latest testing regarding the relationship of these external factors simultaneously. Based on this, the next hypothesis proposed in this study are:

H3: Socialization of advertisements and tax services simultaneously affects taxpayer compliance.

\section{Research Methods}

This research is a quantitative study using a survey method with a questionnaire instrument. The questionnaire was designed using a Likert scale of measurement 1 (Strongly Disagree) - 5 (Strongly Agree). The sample of this research was 107 taxpayers in Jakarta. The number of samples must meet the requirements for determining the minimum number of samples. The number of samples is obtained by multiplying the number of indicators by $5-10$ (Hair, Black, Babin, \& Anderson, 2014) so that the number is deemed to have met the requirements. Data collection was collected randomly. Analysis of research data using multiple regression analysis with the SPSS 25.0 analysis tool. In conducting analysis, this study uses tests, namely reliability and validity tests, classical assumption tests and hypothesis testing. At the end, this research will analyze the coefficient of determination and form a regression equation.

\section{Results And Discussion}

This study consisted of 107 respondents consisting of 64 male (59.8\%) and 43 female (40.2\%). This study was dominated by male respondents with a close difference from female respondents. Based on these results it can be explained that the distribution of data based on the gender representation of respondents is quite even. 
Table 2. Profile - Gender

\begin{tabular}{clc|c|c|c}
\multicolumn{2}{c}{ Description } & Frequency & Percent & Valid Percent & Cumulative Percent \\
\hline Valid & Male & 64 & 59.8 & 59.8 & 59.8 \\
\cline { 2 - 6 } & Female & 43 & 40.2 & 40.2 & 100.0 \\
\cline { 2 - 6 } & Total & 107 & 100.0 & 100.0 & \\
\hline
\end{tabular}

Source: Data SPSS 25.0; $n=107$

Table 3 shows the reliability results where Cronbach's Alpha shows a score of 0.817 for the overall item. If you look at each item, the score is Ads $1=0.780$, Ads $2=$ 0.798, Serv1 $=0.789$, Serv2 $=0.784$, Serv $3=$ 0.785 , Comp $1=0.820$, Comp2 $=0.814$, and Comp $3=0.796$. Thus, from these results all items of Tax dissemination and Tax Service in this study are reliable. Table 3 also shows the score for each item, namely Ads $1=0.914$, Ads2 $=0.902$, Serv1 $=0.836$, Serv2 $=0.905$, Serv $3=0.836$, Comp $1=0.801$, Comp $2=$
0.799, and Comp3 $=0.694$. These results indicate that the Pearson Correlation score for each item is above the r-table score (df-2 = 0.109 ) and the sig score. each item shows a score less than 0.05 . These results explain that all items of Tax dissemination and Tax Service are valid. The test results are based on Cronbach's Alpha score must be above 0.7 for data reliability and Pearson Correlation score (> r-table) with Sig. (> 0.05) from each item to determine the validity of the data (Christian, Purwanto, \& Wibowo, 2020).

Table 3. Reliability and Validity

\begin{tabular}{lrrrr}
\hline \multirow{2}{*}{ Item } & $\begin{array}{c}\text { Cronbach's } \\
\text { Alpha }\end{array}$ & $\begin{array}{c}\text { Cronbach's Alpha } \\
\text { if Item Deleted }\end{array}$ & Correlations \\
\hline Ads1 & & 0.780 & 0.914 & 0.000 \\
Ads2 & & 0.798 & 0.902 & 0.000 \\
Serv1 & & 0.789 & 0.836 & 0.000 \\
Serv2 & 0.817 & 0.784 & 0.905 & 0.000 \\
Serv3 & & 0.785 & 0.836 & 0.000 \\
Comp1 & & 0.820 & 0.801 & 0.000 \\
Comp2 & & 0.814 & 0.799 & 0.000 \\
Comp3 & & 0.796 & 0.694 & 0.000 \\
\hline Source: Data SPSS 25.0; $\mathrm{n}=107$ & & &
\end{tabular}

Before testing the hypothesis, it is necessary to test classic assumptions on the research data. This test includes the normality test, multicollinearity and heteroscedasticity. The normality test in this study uses the PPlot of Regression Standardized Residual method. Based on this method, data is normally distributed if the points are around the line and follow the diagonal direction (Matsaany, Adinda, Amora, \& Fauzy, 2016); (Gao \& Abdul Razak bin Chi, 2013). Figure 1 shows the distribution of the points near and following the direction of the diagonal line. This explains that the data are normally distributed. 


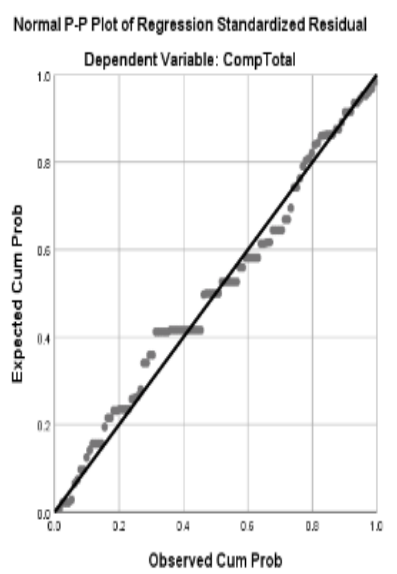

Figure 1. P-P Plot Normality Test Source: Data SPSS 25.0; $n=107$

The multicollinearity test aims to determine whether there is a high correlation between variables in a multiple linear regression model. To find out whether there are multicollinearity symptoms in the data, you can look at the Colliniearity Statistics score where the Tolerance score must be greater than 0.1 and the Variance Inflating Factor (VIF) score must be less than 10 (Won, Wan, \& Sharif, 2017; Hair et al., 2014). Table 4 shows the Tolerance score of tax dissemination variable of 0.736 and the Tolerance score of the Tax Service variable of 0.736 . Both variable scores are above 0.1 . VIF on the Socialization and Tax Service variable shows a score of 1.359 or is below
10. The results of this Colliniearity Statistics explain that there is no multicollinearity in the data. Next, the heteroscedasticity test was carried out to determine whether there was an inequality in the variance of the residuals between observations. This study uses the Glejser method. This test looks at the Sig score where this test score must be greater than 0.05 for each variable (Handaruputri \& Hartono, 2020). Table 4 shows the Sig. The socialization variable is 0.217 and the Tax Service variable is 0.337 . Both variable scores are smaller than 0.05 and at the same time explain that in this test there is no heteroscedasticity disorder so that the next analysis in this study can be continued.

Table 4. Heteroscedasticity Test

\begin{tabular}{r|rr|r}
\hline \multirow{2}{*}{ Model } & \multicolumn{3}{|c}{ Coefficients $^{\text {a }}$} \\
\cline { 2 - 3 } & \multicolumn{2}{|c}{ Collinearity Statistics } & \multirow{2}{*}{ Sig. } \\
\cline { 2 - 3 } & Tolerance & VIF & .217 \\
\hline AdsTotal & .736 & 1.359 & .337 \\
\hline ServTotal & .736 & 1.359 & a. Dependent Variable: Abs_RES \\
\hline & a. Dependent Variable: CompTotal & \multicolumn{3}{c}{ Source: Data SPSS 25.0; $\mathrm{n}=107$}
\end{tabular}

Hypothesis testing in this study compares the t-count score with the t-table and the significance score with probability. If the t-count score is greater than the t-table or the significance score is smaller than the probability, the hypothesis is accepted (Christian, 2017). Table 5 shows that the tcount score for the socialization variable is 2,824 . The result of t-table $(\alpha / 2 ; n-k-1)$ is 1.98326. From these results it can be explained that the $\mathrm{t}$-count is greater than the $\mathrm{t}$ - table. The significance of the socialization variable is 0.006 and the significance of this variable is less than 0.05 . Based on the results of this hypothesis test on the Socialization variable, it can be explained that Hypothesis 1 is accepted, which means explaining that tax dissemination in its various forms influences Taxpayer Compliance in carrying out its obligations to report taxes. This result is in line with research conducted by (Indriyarti \& Christian, 2020) which explains 
that frequent lack of socialization is an important factor in shaping taxpayer awareness. In addition, the effectiveness of the content submitted to taxpayers is a determining factor, especially in answering or resolving problems regarding taxes for taxpayers. Likewise, research conducted by Trisnawati , E., \& Putri, (2014) which uses external factors to help deliver tax information as well as to form awareness for taxpayers. Specifically, regarding socialization, especially in the form of advertising, the effectiveness of advertising has an influence on the formation of taxpayer awareness in Gorontalo (Sulila, 2019). From a global perspective, this is also in line with research conducted by Saad (2014) regarding taxpayers in Malaysia who apparently have inadequate knowledge of the technical income tax system. The aspect of socialization in this case at least can be a supporting factor to overcome the existing problems. Socialization in the form of advertisements both on television and in newspapers can increase the rate of tax filing in Pakistan (Koumpias \& Martinez-Vazquez, 2019). However, research conducted by Wulan et al., (2018) and Waluyo (2014) explains that tax advertising has no impact in shaping taxpayer awareness. There is an indication that the sample characters used are taxpayers who have high awareness as taxpayers. The frequency of advertising that is not accurate or even too frequent can lead to the absorption of the information to be conveyed to the public as taxpayers. In this case there is a need for a strategy in delivering tax information in the form of advertisements to convey the message to be conveyed so that the advertisement regarding the tax being delivered is not considered a form of annoying advertising which will then be easily ignored (Christian, 2019). This also relates to the tax ad format that will be delivered whether it has a dominant form in the aspect of information or interesting content (Christian, 2017). In addition, the taxpayer's background factor can also have an impact on the success of the tax advertisement being delivered. Variety of taxpayer backgrounds such as age, level of education, place of residence or even the ease of accessing or obtaining information about taxes can be a determining factor for public awareness as a taxpayer. In this case, the strategy undertaken by the government to conduct outreach in the form of providing direct services to public places needs to be carried out continuously and it is necessary to increase the frequency and number of service points by increasing cooperation with various educational institutions or companies.

Table 5 also shows that the t-count score of the Tax Service variable is 2,499 . The result of t-table $(\alpha / 2 ; n-k-1)$ is 1.98326 . From these results it can be explained that the $\mathrm{t}$-count is greater than the $\mathrm{t}$-table. The significance of the Tax Service variable is 0.014 . The score of signification of this variable is more than 0.05 . Based on the results of this hypothesis test on the Tax Service variable, it can be explained that Hypothesis 2 is accepted, which means explaining that Tax Services have an impact on Taxpayer Compliance. Existing tax services are either face-to-face (Integrated Service Points) and online information services or in the form of a call center. This result is in line with research conducted by Indriyarti \& Christian (2020) which explains that the services provided by the government are one of the factors that affect taxpayer compliance. Likewise, research conducted by Waluyo (2014) which uses tax services has an impact on taxpayer compliance. In addition, Indrayani \& Suhendra (2017) through their research explained that the quality of service both at the tax office (facilities) and tax officer services can shape taxpayer compliance, especially regarding reporting of annual income tax returns. This indicates that the convenience of the taxpayer's process of carrying out its obligations is also a determining factor for positive experiences. In addition, the complexity of regulations regarding taxes also needs to be conveyed to taxpayers clearly so that taxpayers get a proper understanding and are not confused about what should be reported and paid as an obligation. Regarding the tax service facility itself, it has established standards, one of which also aims to provide convenience and comfort for taxpayers in addition to fulfilling the expectations of the services provided (Oktaviani, Juang, \& Kusumaningtyas, 2017). Looking from a broader perspective such as in Nigeria, the tax services provided by the government, although they have an influence 
on taxpayer compliance, are not significant (Anyaduba \& Oboh, 2019). Even though the tax service is one of the important factors for taxpayers, this does not make it an excuse for not performing their obligations as taxpayers. Therefore, in this case, the excellent service that is satisfactory from the tax service is only a forming factor for the satisfaction of the experience of each taxpayer. However, the satisfaction of the experience felt by taxpayers can give a good impression and impact the willingness to be willing to carry out their obligations in the long term.

The next test is a simultaneous hypothesis test. This test uses a comparison of the F-count score with the F-table and the significance score with probability. If the $\mathrm{F}$ count score is greater than the F-table or the Significance score is smaller than the probability, the hypothesis is accepted (Indriyarti \& Wibowo, 2020; Fensi \& Christian, 2018). Table 5 shows that the Fcount scores simultaneously are 14,595. The results of the F-table $(\mathrm{k} ; \mathrm{n}-\mathrm{k})$ are 3.08. From these results it can be explained that the $\mathrm{t}$ count is greater than the t-table. The simultaneous significance of 0.000 and signification of this variable is less than 0.05 . Based on the results of this simultaneous hypothesis test, it can be explained that Hypothesis 3 is accepted which means that it explains that the Dissemination of Taxes and Tax Services simultaneously affects Taxpayer Compliance. These results are the same as the results of research conducted by Indriyarti \& Christian (2020). From these results it can also be explained that the need for various forms of reminders for taxpayers in establishing tax compliance as a taxpayer. Tax dissemination can be done in the form of public service advertisements that are delivered through print, electronic, online, and face-to-face socialization media. Tax services can be carried out through Appropriate Integrated Services or designated public places or in collaboration with the Directorate General of Taxes. These results are also in line with research conducted by Awaluddin \& Tamburaka (2017). The ease of delivery of information about taxes can shape the level of awareness of taxpayers. In line with this, the service satisfaction felt by taxpayers also creates a sense of comfort for the formation of higher intentions in carrying out tax obligations. Therefore, excellent service and service satisfaction simultaneously affect taxpayer compliance. In relation to taxpayer compliance, various internal and external factors simultaneously have an effect. This also strengthens the research conducted by Lestari \& Wicaksono (2017) and Putri, Devi, \& Amijaya (2020). However, on a slightly different side in the case study of boarding house owners in Semarang, it turns out that factors such as the environment, tax sanctions, and taxpayer awareness do not significantly affect the level of taxpayer compliance (Princesswara \& Iskandar, 2019).

Furthermore, the information in table 5 can explain the form of the regression equation. Based on this table, the regression equation of this study is $\mathrm{Y}=7.018+0.342 \mathrm{X} 1$ $+0.214 \mathrm{X} 2+\mathrm{e}$. These results explain that the influence of the independent variables (Socialization and Tax Services) shows a positive effect seen from the constant value. Taxpayer compliance as variable $\mathrm{Y}$ will increase by $34.2 \%$ if socialization as variable $\mathrm{X} 1$ has an increase of 1 unit. Likewise, the Tax Service factor will affect the Taxpayer's Compliance factor by $21.4 \%$ if the Service has an increase of 1 unit. Based on these results, it can also be explained that the socialization factor is a more dominant factor than the tax service factor in terms of having an influence on taxpayer compliance.

The results of the hypothesis test above explain that the two factors used in the study, namely the Socialization of Taxes and Tax Services, have an influence on Tax Compliance. The magnitude of these two factors has an influence on the Taxpayer Compliance factor which can be seen from the coefficient of determination. The $R$ Square score in table 6 shows a score of 0.219 which explains that the magnitude of Tax dissemination and Tax Service factors has an influence on Taxpayer Compliance, which is 
Table 5. Hypothesis testing

\begin{tabular}{|c|c|c|c|c|c|c|c|c|c|c|}
\hline \multirow[t]{2}{*}{ Hypothesis } & \multicolumn{2}{|c|}{$\begin{array}{l}\text { Unstandardized } \\
\text { Coefficients }\end{array}$} & \multicolumn{3}{|c|}{ Partial } & \multicolumn{3}{|c|}{ Simultaneously } & \multirow[t]{2}{*}{ Prob. } & \multirow[t]{2}{*}{ Results } \\
\hline & $\mathrm{B}$ & Std. Error & $\mathrm{t}$ & Sig. & t-table & $\mathrm{F}$ & F-table & Sig. & & \\
\hline (Constant) & 7.018 & 0.884 & 7.939 & 0.000 & & & & & & \\
\hline Socialization $\rightarrow$ & 0.342 & & 2.824 & .006 & & - & - & - & & Accept H1 \\
\hline $\begin{array}{l}\text { Tax Compliance } \\
\text { Tax Services } \rightarrow \\
\text { Tax Compliance }\end{array}$ & 0.214 & & 2.499 & .014 & 1.98326 & - & - & - & 0.05 & Accept H2 \\
\hline $\begin{array}{l}\text { Socialization \& } \\
\text { Tax Services } \rightarrow \\
\text { Tax Compliance }\end{array}$ & & & - & - & - & 14.595 & 3.08 & $.000^{\mathrm{b}}$ & & Accept H3 \\
\hline
\end{tabular}

Source: Data SPSS 25.0; $n=107$

$21.9 \%$. There are other factors $(78.1 \%)$ that also affect Taxpayer Compliance. Research conducted by Handoko, Toni, \& Simorangkir (2020) and Mubarok, Faridah, \& Masnila (2020) uses the tax sanction factor to explain the effect on taxpayer compliance. Another study, Darmayanti (2019), uses tax amnesty as another factor that explains taxpayer compliance. Based on these results it can be explained that various factors can be used as a government strategy in shaping the awareness of taxpayers in Indonesia.

Table 6. Coefficient of Determination

\begin{tabular}{llrrr}
\hline \multicolumn{4}{c}{ Model Summary $^{\mathbf{b}}$} \\
\hline Model & $\mathrm{R}$ & $\mathrm{R}$ Square & Adjusted R Square & Std. Error of the Estimate \\
\hline 1 & $0.468^{\mathrm{a}}$ & 0.219 & 0.204 & 1.53930 \\
\hline a. Predictors: (Constant), ServTotal, AdsTotal & & \\
b. Dependent Variable: CompTotal & & \\
\hline Source: Data SPSS 25.0; $\mathrm{n}=107$ &
\end{tabular}

\section{Conclusions}

Based on the results and discussion above, this study explains that Taxpayer Compliance is partially influenced by Tax dissemination and Tax Service factors. This study also explains that Tax dissemination and Tax Service factors simultaneously contribute to the awareness of taxpayers to comply with their obligations according to a predetermined time in accordance with applicable laws and regulations. The synergy between socialization in the form of advertisements in print, electronic and online media needs to be balanced by increasing tax services at various points. This makes it possible to reach points where it has been difficult to get direct information about the procedures and regulations for tax filing / reporting. This proximity in the form of tax services makes it possible to form a positive impression regarding taxes for the taxpayer. Thus, the awareness that is formed for Taxpayers will be positive in the long term. Characteristics of taxpayers such as novice taxpayers are one of interesting inputs to do in the research. The level of tax knowledge for the group taxpayers will be closely related to the awareness of taxpayers in carrying out their obligations. This has an indirect impact on the level of compliance as a taxpayer.

\section{Reference}

Afritenti, H., Fitriyani, D., \& Susfayetti, S. (2020). Faktor-Faktor Yang Mempengaruhi Kepatuhan Wajib Pajak Orang Pribadi Yang Melakukan Pekerjaan Bebas Yang Terdaftar Di Kpp 
Pratama Jambi. Jambi Accounting Review(JAR), 1(1), 63-79.

Andreas, A., \& Savitri, E. (2015). The Effect of Tax Socialization, Tax Knowledge, Expediency of Tax ID Number and Service Quality on Taxpayers Compliance With Taxpayers Awareness as Mediating Variables. 2nd Global Conference on Business and Social Science (GCBSS), 163 - 169. https://doi.org/10.1016/j.sbspro.2015.11 .024

Anyaduba, J. O., \& Oboh, T. (2019). Determinants of Tax Compliance Behaviour under the Self-Assessment Scheme in Nigeria. Accounting and Finance Research, 8(2), 13-31. https://doi.org/10.5430/afr.v8n2p13

Arviana, N., \& W, D. I. (2018). Faktor-Faktor Yang Mempengaruhi Kepatuhan Wajib Pajak Orang Pribadi. Jurnal Muara Ilmu Ekonomi Dan Bisnis, 2(1), 146-154.

Awaluddin, I., \& Tamburaka, S. (2017). The Effect of Service Quality and Taxpayer Satisfaction on Compliance Payment Tax Motor Vehicles at Office One Roof System in Kendari. The International Journal of Engineering and Science (IJES), 6(11), 25-34. https://doi.org/10.9790/18130611012534

Benk, S., Çakmak, A. F., \& Budak, T. (2011). An Investigation of Tax Compliance Intention: A Theory of Planned Behavior Approach. European Journal of Economics, Finance and Administrative Sciences, (28), 180-188.

Christian, M. (2017). Pengaruh Unsur-Unsur Iklan Pajak: Hiburan, Informatif Dan Nilai Iklan. Bricolage: Jurnal Magister Ilmu Komunikasi, 3(02), 156-164. https://doi.org/10.30813/bricolage.v3i02 .936

Christian, M. (2019). Telaah Keniscayaan Iklan Di Kanal Youtube Sebagai Perilaku Khalayak Di Kalangan Milenial (Study The Inevatibility of Advertisements on Youtube Channels as Audience Behavior among Milennials). Bricolage: Jurnal Magister Ilmu
Komunikasi, 5(2), 141-158.

Christian, M., Purwanto, E., \& Wibowo, S. (2020). Technostress Creators on Teaching Performance of Private Universities in Jakarta During Covid-19 Pandemic. Technology Reports of Kansai University, 62(6), 2799-2809.

Damayanti, T. W. (2012). Changes On Indonesia Tax Culture, Is There A Way? Studies Through Theory Of Planned Behavior. Journal of Arts, Science \& Commerce, III(4(1)), 8-15.

Darmayanti, N. (2019). The Effects Of Tax Sanction, Fiscal Services, Tax Knowledge, And Tax Amnesty On Taxpayer Compliance. Proceedings of the 1st International Conference on Business, Law And Pedagogy, ICBLP. https://doi.org/10.4108/eai.13-22019.2286025

Dirjen_Pajak. (2019). Laporan Kinerja Direktorat Jenderal Pajak 2019. Retrieved from https://www.pajak.go.id/sites/default/fil es/2020-02/LAKIN DJP 2019.pdf

Fensi, F., \& Christian, M. (2018). Determinan Citra Merek Pada Iklan Produk Gawai "Vivo" Berdasarkan Aspek "Celebrity Endorser." Bricolage: Jurnal Magister Ilmu Komunikasi, 4(2), 163-179.

Gao, Y., \& Abdul Razak bin Chi. (2013). A Multiple Regression Analysis on Influencing Factors of Urban Services Growth in China. Technology and Investment, 4, 1-5.

Hadiwijaya, H., \& Febrianty, F. (2019). The Effect of Service Quality and Tax Sanctions on Service Satisfaction. Etikonomi, 18(2), 197-208. https://doi.org/10.15408/etk.v18i2.7428

Hai, O. T., \& See, L. M. (2011). Behavioral Intention of Tax Non-Compliance among Sole-Proprietors in Malaysia. International Journal of Business and Social Science, 2(6), 142-152.

Hair, J. F., Black, W. C., Babin, B. J., \& Anderson, R. E. (2014). Multivariate Data Analysis (7th ed.). Essex: Pearson 
Education Limited.

Handaruputri, T. L., \& Hartono, B. (2020). The Relationship of Knowledge Codification towards Organizational Performance in Indonesian Construction Industry. Journal of International Conference Proceedings, 3(1), 255-266. https://doi.org/10.32535/jicp.v2i4.801

Handoko, Y., Toni, N., \& Simorangkir, E. N. (2020). The Effect of Tax Knowledge and Tax Sanctions on Taxpayer Compliance at the Tax Office (KPP) Pratama, Medan Timur through Tax Awareness as an Intervening Variable. International Journal of Research and Review, 7(9), 294-302.

Hary, N. E. F., Kertahadi, K., \& Riyadi, R. (2014). Evaluasi Pelayanan Prima Dalam Perpajakan (Studi Pada Kantor Pelayanan Pajak Pratama Malang Utara Dan Malang. Jurnal Mahasiswa Perpajakan, 2(1).

Indrayani, E., \& Suhendra, E. S. (2017). The Influencing Factors Of Personal Tax Compliance On Reporting Annual Income Tax Return. Jurnal Ilmiah Ekonomi Bisnis, 22(3), 178-186.

Indriyarti, E. R., \& Christian, M. (2020). The Impact Of Internal And External Factors On Taxpayer Compliance. Journal of Business \& Applied Management, 13(1), 33-48.

Indriyarti, E. R., \& Wibowo, S. (2020). Bisnis Kesehatan Berbasis Digital: Intensi Pengguna Aplikasi Digital Halodoc. Jurnal Pengabdian Dan Kewirausahaan, 4(2), 112-121.

Juniarti, J., Noersanti, L., \& Susanti, E. H. (2018). The Impact of Modern Tax System Against Transport Workers Taxpayer Compliance Online. 5th Annual International Conference on Accounting Research (AICAR 2018), 221-223.

https://doi.org/10.2991/AICAR18.2019 .48

Koumpias, A. M., \& Martinez-Vazquez, J. (2019). The Impact of Media Campaigns on Tax Filing: Quasi-
Experimental Evidence from Pakistan. Allied Social Science Associations (ASSA), 1-29. Atlanta: American Economic Association.

Lestari, T., \& Wicaksono, M. (2017). Effect Of Awareness, Knowledge And Attitude Of Taxpayers Tax Compliance For Taxpayers In Tax Service Office Boyolali. International Journal of Economics, Business and Accounting Research (IJEBAR), 1(1).

Marandu, E. E., Mbekomize, C. J., \& Ifezue, \& A. ander N. (2015). Determinants of Tax Compliance: A Review of Factors and Conceptualizations. International Journal of Economics and Finance, 7(9), 207-218. https://doi.org/10.5539/ijef.v7n9p207

Matsaany, B., Adinda, G., Amora, R., \& Fauzy, A. (2016). Analisys of affecting Factors Slavery Policy (Case Study: Global Slavery Index 2014). International Seminar on Science, 1-15. Bogor: IOP Science.

Maulida, R. (2018). Manfaat Pajak: Melihat Kontribusi Nyata Anda dalam Pembangunan Nasional. Retrieved January 2, 2021, from online-pajak.com website: https://www.onlinepajak.com/tentang-pajak/manfaat-pajak

Mubarok, M. H., Faridah, F., \& Masnila, N. (2020). The Effect of Taxpayer Awareness and Tax Sanctions on Compliance in Paying Land and Building Taxes. 3rd Forum in Research, Science, and Technology (FIRST 2019). https://doi.org/10.2991/assehr.k.200407. 031

Oktaviani, A. A., Juang, F. T., \& Kusumaningtyas, D. A. (2017). The Effect of Knowledge and Understanding Taxation, Quality of Tax Services, and Tax Awareness on Personal Tax Compliance. Indonesian Management and Accounting Research, 16(2), 33-45.

Princesswara, P., \& Iskandar, D. D. (2019). Determinant Factors Of Tax Compliance Level Of Boarding House Business Owners In Supporting Locally-Generated Revenue Of 
Semarang. Media Ekonomi Dan Manajemen, 34(1), 36-49. https://doi.org/10.24856/mem.v34i1.816

Putri, K. P., Devi, M. C., \& Amijaya, D. T. (2020). Knowlwedge Of Taxation And Fiscus Service On Taxpayers Compliance. Dinasti International Journal of Economics, Finance \& Accounting, $\quad 1(1), \quad 8-20$. https://doi.org/10.38035/dijefa.v1i1.200

Rahmawati, R., \& Yulianto, A. (2018). Analysis of the Factors Affecting Individual Taxpayers Compliance. Accounting Analysis Journal, 7(1), 1724.

https://doi.org/10.15294/aaj.v5i3.18411

Saad, N. (2014). Tax Knowledge, Tax Complexity and Tax Compliance: Taxpayers' View. Procedia - Social and Behavioral Sciences, 109, 1069 - 1075. https://doi.org/10.1016/j.sbspro.2013.12 .590

Savitri, E., \& Musfialdy, M. (2016). The Effect of Taxpayer Awareness, Tax Socialization, Tax Penalties, Compliance Cost at Taxpayer Compliance with Service Quality as Mediating Variable. Procedia - Social and Behavioral Sciences, 219(682-687). https://doi.org/10.1016/j.sbspro.2016.05 .051

Setiyoningrum, A. T., Tinangon, J., \& Wokas, H. R. N. (2014). Analisis Pengaruh Sosialisasi Perpajakan, Kualitas Pelayanan Fiskus Dan Sanksi Perpajakan Terhadap Kepatuhan Wajib Pajak Orang Pribadi Di Kantor Pelayanan Pajak Pratama Manado. Jurnal Riset Akuntansi, 9(4), 50-62.

Siat, C. C., \& Toly, A. A. (2013). FaktorFaktor yang Mempengaruhi Kepatuhan Wajib Pajak dalam Memenuhi Kewajiban Membayar Pajak di Surabaya. TAX \& Accounting Review, 1(1), 41-48.
Sulila, I. (2019). The Effect Of Effectiveness Of Advertising Tax Collection And Material Compliance With Regional Revenue Of Gorontalo. Jurnal Ilmu Administrasi (JIA), XVI(2), 179-193.

Tarmidi, D., Suryati, A., \& Purwaningsih, S. (2020). Tax Evasion: Impact of Internal and External Factors, An Individual Tax Payer Perception. International Journal of Academic Research in Business and Social Sciences, 10(5), 675-685. https://doi.org/10.6007/IJARBSS/v10i5/7240

Trisnawati , E., \& Putri, I. R. (2014). Pengaruh Pelayanan Aparat Pajak, Iklan Pajak, dan Kesadaran Wajib Pajak Terhadap Kepatuhan Wajib Pajak yang Terdapat di KPP Pratama Jakarta Pademangan Pada Tahun 2011. Jurnal Akuntansi, 14(1), 59-80.

Waluyo. (2014). Analisis Pemahaman Wajib Pajak Dan Iklan Otoritas Pajak Terhadap Tingkat Kepatuhan Wajib Pajak. Akuntabilitas, VII(3), 177-184.

Won, N. C., Wan, C. Y., \& Sharif, M. Y. (2017). Effect of Leadership Styles, Social Capital, and Social Entrepreneurship on Organizational Effectiveness of Social Welfare Organization in Malaysia: Data Screening and Preliminary Analysis. International Review of Management and Marketing, 7(2), 117-122.

Wulan, M., Suhartini, T., \& Bahri, E. S. (2018). Analysis of the Influence of Tax Service, Tax Advertising, and Zakat Policy as a Reduction of Taxable Income to Tax Paying Compliance for Individual Taxpayers in the Tax Service Office Pratama Sawangan, Depok, West Java. International Journal of Zakat, $3(1)$, 71-89. https://doi.org/10.37706/ijaz.v3i1.69 